\title{
TOWARD PARTICIPATORY MANAGEMENT OF RENEWABLE ENERGY RESOURCES (WIND-FARM) IN NORTHEASTERN BRAZIL
}

\author{
caminhos para uma gestão participativa dos recursos energéticos \\ de matriz renovável (parques eólicos) no Nordeste do Brasil
}

\author{
Adryane Gorayeb * \\ Christian Brannstrom **
}

\begin{abstract}
Resumo
Apesar da energia eólica ser considerada uma matriz energética "limpa", estudos apontam que a implantação de parques eólicos no Nordeste brasileiro está causando diversos impactos sociais e ambientais negativos às populações que vivem no litoral. Esta pesquisa teve como intuito demonstrar que o investimento em energia eólica no Brasil, com enfoque no estado do Ceará, apesar de ter sido forjado a partir de um discurso conservacionista e regionalista, na realidade, direciona os benefícios da geração de energia eólica para grupos externos, com ausência de retorno financeiro local e, de forma mais agravante, causando prejuízos materiais $\mathrm{e}$ imateriais aos moradores que vivem próximo às usinas instaladas. O estudo revelou que as leis que regem o ordenamento da atividade no Brasil facilitam a implantação dos parques eólicos em detrimento da boa aceitação popular, sendo comumente utilizados mecanismos para "invisibilizar" os moradores locais. No final, foram sugeridas medidas para um melhor gerenciamento das políticas de implantação de parques eólicos no Ceará, de modo a possibilitar que as comunidades locais sentem à mesa de negociação e se beneficiem diretamente com os lucros do mercado de geração de energia eólica.
\end{abstract}

Palavras chave: Energia Eólica; Políticas Públicas; Nordeste do Brasil; Impactos Sociais.

\begin{abstract}
Although wind power is a "clean" energy source, studies show that wind-farm implementation in northeastern Brazil is causing diverse social and negative environmental impacts to people who live in coastal areas, especially traditional fishers, small farmers, runaway slave communities (quilombolas), and indigenous groups. Social opposition to wind farms grows daily, and people allied with social movements, associations, human rights organizations, and universities have made many local interventions to stop construction. This research aims to demonstrate that even though investments in Brazilian wind power, especially Ceará state, were based on a conservationist and regionalist discourse, wind power benefits actually flow to outside groups without financial returns accruing locally, and, even worse, causing material and non-material damages to people who live near wind farms. This study reveals that laws regulating wind-power development in Brazil facilitate the implementation of wind farms to the detriment of broad social acceptance because it is a means to make local residents "invisible," as in the case of exclusion of communities on maps used to obtain environmental licenses or land-title fraud (grilagem) of collective and historical land claims. Finally, we suggest measures for better control of policies for wind-farm development in Ceará that would make it possible for communities to negotiate as equals with wind-power investors and obtain benefits from the profitability of wind-power generation.
\end{abstract}

Key words: Wind Energy, Public Policies; Northeastern Brazil, Social Impacts

\begin{abstract}
Resumen
Aunque la energia eólica sea considerada como una fuente energética "limpia," las investigaciones muestran que la implantación de campos eólicos en el nordeste brasileño está generando diversos impactos sociales e ambientales negtivos a las poblaciones que se encuentran en el litoral, especialmente a los pescadores tradicionales, a los campesinos, a los quilombolas y a los pueblos indígenas. La oposición social a la construcción de los campos eólicos en el litoral aumenta cada dia, y diversas actuaciones para paralizar las obras de construcción vienen siendo realizadas por las poblaciones locales con ayuda de los movimientos sociales. En esta investigación mostramos que las inversiones en energia eólica generan beneficios a los grupos externos, sin contribución financiera local y, para agravar la situación, generan daños materiales y no materiales a la población local que vive cerca de los campos eólicos. Se evidenció ademas que las leyes sobre la energia eólica facilitan la construcción de campos eólicos en contra del apoyo social popular, siendo utilizados mecanismos para "invisibilizar" a los habitantes locales, como lo es la exclusión de las comunidades en los mapas utilizados para el licenciamiento ambiental o para obtener ilegalmente (grilagem) las tierras de uso coletivo e histórico. Finalmente, se destacan medidas para la planificación y el mejor ordenamiento de los campos eólicos en Ceará para que las comunidades locales puedan negociar de igual con los inversionistas y obtener su parte de la producción de ganancia de la energia eólica.
\end{abstract}

Palabras clave: Energia eólica; Políticas públicas; Impactos sociales; Nordeste del Brasil

(*) Lecturer, Doctor of the Federal University of Ceará (Universidade Federal do Ceará) - Campus do Pici, Bloco 911, CEP 60.440-900, Fortaleza (CE), Brasil. Tel: (+ 55 85) 33669855 - adryanegorayeb@yahoo.com.br

(**) Lecturer, Doctor of the Texas A\&M University, MS 3147, 810 O\&M Building, College Station, Texas, EUA, 77845, tel +1979845 5923, cbrannst@geos.tamu.edu 


\section{INTRODUCTION}

Wind is considered to be a renewable source of energy tapped by converting translational to rotational kinetic energy through the use of turbines to generate electricity or windmills for mechanical work such as pumping water.

According to Jabber (2013), the use of wind power began with by sailing ships in maritime transport thousands of years ago. However, wind was seen as an important source of electrical power only at the start of the nineteenth century and, one century later, with the first petroleum crisis of 1973, when western counties had sufficient political interest and investment to develop and produce equipment to generate commercial-scale wind power. Several countries, including Brazil, conducted research on using wind to produce electricity (DINCER, 2000; CEARÁ, 2001). Meanwhile, market stimulus experiments in California during the 1980s and in Denmark and Germany in the 1990s encouraged wind-power performance to reach significant levels in terms of power generation and economic cost (BRASIL, 2001).

Wind power is clean, friendly to the environment and, in technological terms, compatible with utility-scale power generation. It also has reduced environmental pollution and water consumption, produces no CO2 (SAIDUR et al., 2011), and has low risk of supply insecurity (VRIES et al., 2007). Project installation is rapid compared to other power sources because wind turbines are produced at industrial scale and may be quickly installed and connected to electrical distribution grids (CEARÁ, 2001).

Wind power is seen as ideal because it does not pollute, does not require fuel, does not generate toxic gases and does not produce radioactive waste (JABBER, 2013). Dincer (2000) argues that a major solution to global environmental problems may be found in renewable energy technology, which could provide the basis for sustainable global development, especially considering problems associated with emission of pollutants.

Globally, wind power could satisfy $1,700 \mathrm{TW}$, or $50 \%$ of total electrical power demand by 2030 using only $1.17 \%$ of the terrestrial surface with 3.8 million $5 \mathrm{MW}$ turbines (JACOBSON; DELUCCHI, 2011). However, with the low potential density of 0.5 to 1.5 Watts per square meter, other authors estimate that a wind potential of 1,075 $\mathrm{GW}$ would require 160.9 million hectares of land, possibly creating a global land rush that would generate social conflicts as a result of the energy transition from fossil fuels to renewable power (SCHEIDEL; SORMAN, 2012). Pasqualetti (2011) argues that social conflicts relating to renewable power result from the "imposition" of wind power without compensation or mitigation when investors value technical criteria such as wind efficiency and quality above social considerations such as the productive and emotional linkages between people and territory.

Precursors of current wind turbines originated in Germany with blade manufacturing from composite materials (HUTTER, 1995), the technological advances that made it possible to motivate the industry and encourage global technological dissemination. The first commercial wind turbine linked to a public electricity grid was installed in Denmark in 1976 (BARCELLA; BRAMBILLA, 2012) and by 2004 there were more than 30,000 installed globally (EWEA, 2005).

At present the wind-power industry is present in more than 80 countries with India, China and Latin America considered to be growing markets. Leaders in installed capacity are China (114,609 MW), USA (65,879 MW), Germany (39,165 MW), Spain (22,987 MW), India (22,465 MW) and the United Kingdom (12,440 MW) (GWEC, 2014). At the end of 2014 wind power supplied the equivalent of $39 \%$ of electrical power demand in Denmark, 20\% in Ireland, Portugal and Spain, and $4.9 \%$ in USA (GWEC, 2014). By 2020 approximately $12 \%$ of world electricity will be supplied by wind (EWEA, 2005). 
Wind power potential varies temporally according to the natural resource characteristics of particular sites and land use, technology, and economic, social, juridical, and institutional aspects of each country (VRIES et al., 2007), in addition to the efficiency of the energy producing devices.

A wind farm is comprised of turbines organized in a particular site in consideration of wind velocity, operating conditions, terrain roughness and thermal stability in the atmosphere. Geographical proximity of turbines has the advantage of reducing costs relating to land rental, equipment to prepare land for construction, and management of maintenance procedures. Wind quality is critical to analyses of technical viability of sites for wind farms because, according to the literature, wind speeds below 2.5 to $3 \mathrm{~m} / \mathrm{s}$ do not justify wind power investments, while velocity greater than 12 to $15 \mathrm{~m} / \mathrm{s}$ activate automatic systems to restrict power capacity. Very strong winds, greater than $25 \mathrm{~m} / \mathrm{s}$, activate automatic protection systems that turn off turbines (SILVA, 2006; SOUSA, 2010).

In technical terms, turbines may be classified as small if they generate less than $500 \mathrm{KW}$, medium if capacity is between 500 and $1000 \mathrm{KW}$, and large if their capacity exceeds $1 \mathrm{MW}$ (ANEEL, 2005). Turbines may be connected to a general electrical grid, as in the case of Brazil, or their output may be directed to supply power to isolated communities, residences, or small-scale rural activities (ALBIERO et al., 2014). Wind turbines may be sited in onshore (terrestrial) or offshore (marine) environments.

Brazil's 2014 total installed capacity was $133.9 \mathrm{GW}$, supplied by hydroelectric dams $(66.6 \%)$, natural gas (9.4\%); biomass (9.2\%); petroleum (5.9\%); wind (3.6\%); coal (2.5\%); nuclear (1.5\%); industrial gas (1.2\%) and biogas (0.1\%) (BRASIL, 2015).

Although wind power is not significant in percentage terms, Brazil is the leader among Latin American and the Caribbean countries. In 2014, Brazil ranked tenth globally, with $5.96 \mathrm{GW}$ installed capacity from 238 wind farms. Notably, in 2014 Brazil showed a 72\% increase in wind power compared to 2013, retaining its position as one of the countries with greatest increases in wind-power production (GWEC, 2014). Mean household electricity consumption in Brazil in 2014 was $167 \mathrm{KWh}$; by comparison, wind power supplied 6 million residences per month, or 18 million people (GWEC, 2014), making the main producing states, Rio Grande do Norte, Ceará, and Rio Grande do Sul, practically energy self-sufficient.

However, it is important to emphasize that capacity, in MW, is not the same as energy produced. Turbines do not have $100 \%$ efficiency. But the efficiency (capacity factor) of turbines in coastal Ceará is considered very high in comparison with other world regions, especially during the dry period (FILGUEIRAS; SILVA, 2003). For example, in October 2015 wind turbines in northeastern Brazil reached a record with capacity factor of $86 \%$ (ABEEÓLICA, 2015a, 2015b), while in Texas, USA, wind turbines have a capacity factor of approximately 30\% (BRANNSTROM et al. 2015).

This situation resulted from study and investment that began at the end of the 1970s, when the Northeastern Development Agency (Superintendência do Desenvolvimento do Nordeste; SUDENE) and the São Francisco Hydroelectric Company (Companhia Hidrelétrica do São Francisco; CHESF) installed 81 anemometers in Brazil's northeastern region. In the late 1980s studies led by the Federal University of Paraíba (Universidade Federal da Paraíba; UFPB) concluded that the sites with greatest wind-power potential were Rio Grande do Norte, Bahia and the Fernando de Noronha archipelago, where South America's first wind turbine for commercial power was installed unsuccessfully (ARAÚJO; FREITAS, 2008). At the same time, Brazilian and German aerospace groups developed a turbine capable of generating $100 \mathrm{KW}$ (ANEEL, 2005).

Simas; Pacca (2013), in work supported by the Brazilian Association of Wind Energy (Associação Brasileira de Energia Eólica do Brasil - ABEEOLICA), argued that wind power could contribute to Brazil's sustainable development. In addition to being more labor intensive than fossil 
fuel power generation, wind power could create 330,000 jobs per year by 2020 , of which $70 \%$ would be direct employment in operation and construction. Another advantage of the Brazilian case is that wind power could supply energy needs of isolated populations because small turbines are capable of meeting specific needs with low wind speeds (ANEEL, 2005).

On the other hand, the industry that supplies the market with parts and equipment and the firms that build and manage wind farms in Brazil report several problems relating to infrastructure, such as poor roads, lack of transmission lines linking wind farms to substations operated by CHESF or the Ceará Electric Company (Companhia Elétrica do Ceará; COELCE), lack of technological education, lack of factories specialized in producing parts and components of turbines, and lack of vehicles suitable for transporting large freight such as turbine blades. There is no consistent national or regional public policy that sets social goals relating to wind-power benefits to bring funds to regions of wind farms, train workers, and invest in siting factories and technological advances.

Brazil, similarly to the USA (BOHN; LANT, 2009; BRANNSTROM et al., 2015), has strong fiscal incentives that help the development of the wind-power sector. As an example of the importance of these incentives to the Brazilian wind-power sector, Pires (2011) highlights the importance of the Renewable Energy Incentive Program (Programa de Incentivo às Fontes Alternativas de Energia Elétrica; Proinfa) for stimulating the market and using auctions starting in 2004 with the goal of increasing the role of renewable energy. At present, Profina finances around $95 \%$ of wind projects (SILVA et al., 2016). Another factor is the exemption of wind farms from value added taxes (ICMS) and other taxes (PIS/Cofins e Pasep), which are important sources of revenue for municipalities, states, and federal government (PIRES, 2011).

This study aims to analyze policies for implementing wind power in Brazil, focusing on the northeastern region, with the goal of indicating paths for better planning of wind farms considering problem areas linked to the sector in Ceará state, which is responsible for a large portion of environmental and social impacts on traditional coastal communities (MEIRELES et al., 2015; MEIRELES et al., 2013; MENDES et al., 2016). Based on the analysis we emphasize a broad view of the problems surrounding policies for wind farms in the Northeast, especially issues relating to the lack of land-tenure security among traditional people and the fragility of legal systems that guarantee of the rights of residents of these communities.

\section{METHODOLOGY}

We have studied this topic since 2008 and conducted periodic field work with interviews, meetings with community leaders and informative meetings in various traditional communities in coastal Ceará where wind farms were built. The research methods are based in a critical reading of documents that comprise the simplified environmental report (relatório ambiental simplificado; RAS) for wind farms in Ceará, in addition to evaluation of federal, state, and municipal legislation relating to wind farms and their position in relation to potential environmental impacts.

\section{WIND POWER IN CEARÁ: THE VANGUARD STATE IN BRAZILIAN WIND-FARM IMPLEMENTATION}

The history of wind power in Brazil is directly related to Ceará state, which developed decisively in the 1990s. This period is when studies were published referring to wind-power potential concentrated in Ceará and Pernambuco states. Surveys were initiated for towers between 30 and $50 \mathrm{~m}$ in height at coastal locations in Ceará, Bahia and Paraná states, in addition to sites in Minas Gerais that had been studied since 1983 (ARAÚJO; FREITAS, 2008, ANEEL, 2005). Strategically, Ceará's government established the first utility-scale wind-energy projects, attracting international 
and domestic investors. In 1993 towers for prospective wind potential were installed by COELCE and CHESF, which made it viable to install Brazil's first technical demonstration site in 1996 in Mucuripe, Praia Mansa (Fortaleza), with 1.2 MW capacity (CEARÁ, 2001). In 2000, these turbines were refurbished to generate double the power (4 turbines, $600 \mathrm{KW}$ each) (ANEEL, 2005). Also, a CHESF report indicated that wind potential in coastal Ceará and Rio Grande do Norte was 9.55 $\mathrm{TWh} /$ year and $2.96 \mathrm{TWh} /$ year, respectively, requiring occupation of $10 \%$ of costal land in Ceará (ANEEL, 2005).

Supported by the National Electricity Agency (Agência Nacional de Energia Elétrica; ANEEL) and the Science and Technology Ministry (Ministério da Ciência e Tecnologia), the Brazilian Wind Energy Center (Centro Brasileiro de Energia Eólica) at the Federal University of Pernambuco (Universidade Federal de Pernambuco; UFPE) published in 1998 the first version of the Northeastern Region Wind Energy Atlas. Continuation of this work resulted in the Panorama of Brazilian Wind Potential in 2003. The leader in this process, Ceará state developed studies between 1998 and 2000, which used wind-velocity measurements to verify that July is extremely favorable for wind power on the coast: for more than $90 \%$ of the time wind velocity was between 7 and $13 \mathrm{~m} / \mathrm{s}$, which corresponds to the maximum aerodynamic frequency of the vast majority of wind turbines (CEARÁ, 2001). In 1999 two important wind farms were established: (i) the Taíba wind farm, in the western coast of the state, which is considered to be Brazil's first to perform as an independent producer, capable of generating $5 \mathrm{MW}$ and (ii) the Prainha wind farm, on the east coast, with capacity of 10 MW (CEARÁ, 2001; ANEEL, 2005).

In 2001 the state government, through its infrastructure secretary, published the "Atlas of Ceará Wind Potential" ("Atlas do Potencial Eólico do Estado do Ceará"), which estimated wind velocity at the 50 to $70 \mathrm{~m}$ height, emphasizing that dune areas had $9 \mathrm{~m} / \mathrm{s}$ mean annual wind velocity. The study estimated $12 \mathrm{TWh}$ usable potential power at $50 \mathrm{~m}$ height and $51.9 \mathrm{TWh}$ at $70 \mathrm{~m}$ height for mean annual wind greater than $7 \mathrm{~m} / \mathrm{s}$ (CEARÁ, 2001). In 2003, Brazil's largest wind farm was the Prainha site and Ceará's installed capacity was 73\% of Brazil's total (ANEEL, 2005).

To understand Ceará's rapid growth in wind power, consider that predictions made in 2008 for 2009 estimated that wind power in the state would attend to $20 \%$ of domestic demand (LIMA, 2009), while in 2014 Ceará's wind energy was capable of supplying double the state's population (ABEEOLICA, 2015).

This historical view provides perspective for analyzing the development of Cearás wind power not only in terms of quantitative and technical data, but also through the political discourse that enabled the arrival of outside investors and the concession of fiscal incentives and logistical benefits to firms that showed interest in implementing wind farms in Ceará. Within the framework of public-private partnerships, the technical documents that encouraged the implementation of wind farms diffused ideas that promoted Ceará's territory as the locus of natural geographic suitability for generating wind power because it had semi-arid climate in a coastline extending for $573 \mathrm{~km}$, which guarantees good quality and constant wind nearly all year.

Ceará's winds are most intense during the daytime because of differential heating of land and ocean and its ocean breeze is influenced by the east-southeast trade winds (FERREIRA; MELLO, 2005). The geographical location of 3 degrees south of the Equator creates low temperature variability while diurnal temperature fluctuations between land and sea contribute to enhanced wind seasonality.

On the other hand, Ceará's wind seasonality is complementary to the hydraulic regime dominating the generation of hydroelectricity in Brazil, as the wind potential in Ceará is greatest precisely at the time when reservoirs are at their lowest levels, during the second half of the calendar year. This natural factor creates complementarity with Brazil's hydraulic regime because most wind-power generation is during the dry period when the costs associated with hydropower, and risks of deficits, 
are greatest (SILVA et al., 2016). Thus, wind serves as a virtual reservoir assuring hydropower and permitting rational use (ABEEOLICA, 2015; GWEC, 2014; CEARÁ, 2011; ANEEL, 2005; SILVA; CÂNDIDO, 2015; SCHULTZ et al., 2005). This is why grid-connected wind power, managed by CHESF, became one of the alternatives to complementary power generation in Brazil, as shown by the fact that in 2014 drought and low reservoir levels encouraged monthly production records for wind and thermal power generation (GWEC, 2014).

This context helps explain how wind power is seen institutionally as a rational way to use Ceará's natural resources. According to the state's discourse, seen in the foundational document of Ceará's wind power, the "tenacious creativity of Ceará's people" (CEARÁ, 2001) induces innovative alternatives that lead to solutions for climate challenges imposed by the hydraulic regime of low rainfall and long droughts associated historically with social problems, such as the death of livestock, destruction of crops, and hunger among the rural population, arising in a traditionally agro-pastoral economy.

The same document reinforces the idea that renewable energy production makes Ceará a pioneer in Brazil in applying the principles established in the United Nations Framework Convention on Climate Change, which aimed to reduce greenhouse gas emissions. These commitments contradicted the government's policy of "simplifying the detailed and lengthy environmental studies required of traditional sources of power generation" (CEARÁ, 2001) when, in the middle of Brazil's biggest energy crisis, the federal government published a regulation (BRASIL, 2001b) that instituted simplified environmental licensing for energy projects considered to have low environmental impact, including wind farms and other renewable energy projects.

This new regulation, which replaced a 1997 regulation that called for environmental impact studies and assessments (EIA/RIMA) (Brasil, 1997) for wind farms, required investors to present only a simplified environmental report (RAS), with a declaration of the technician responsible stating that the project had low potential for environmental impact. In Ceará, Montenegro (2013) indicated that a 2012 resolution of the state environmental council determined that a wind farm was an activity considered to be medium impact. However, the same author suggested that diverse legal readings existed in the state because the state's Regional Federal Tribunal (Tribunal Regional Federal do Ceará), in a 2009 decision, determined that wind farms had small-scale environmental impacts requiring only the production of the RAS.

The questionable legal procedure for requiring environmental licenses was criticized by other branches of state government in a 2010 technical document, which published the contents of a report approving a loan from a public Brazilian bank. This report indicated that wind farms in coastal areas should conduct the EIA/RIMA because they would be built in Permanent Protection Areas (APP) (CEARÁ, 2010b).

\section{SIMPLIFIED ENVIRONMENTAL REPORT (RAS): INSTRUMENT FOR EMERGENCY POLICY OR MEANS TO LEGITIMIZE THE ABUSE OF PRIVATE CAPITAL IN COASTAL CEARÁ?}

The simplified environmental report (RAS) was instituted by federal law in 2001 through Resolution 279 (27 July) (Brasil, 2001b), and aimed to establish simplified procedures for environmental licensing and a 60-day maximum period for licensing of projects that were seen as necessary to increase electricity supply in Brazil.

This law was created under a special regime during the middle of Brazil's biggest electricity crisis and under the imperative of attending to the urgency of a provisional measure (1 June 2001) that created a Management Board for the Electrical Energy Crisis (Câmara de Gestão da Crise de Energia Elétrica) to "propose and implement emergency measures relating to the critical hydro- 
logical situation to meet demand and supply of electrical energy, thus avoiding unanticipated and unforeseen interruptions to electricity supply".

This crisis, known as "blackout" or apagão, was motivated by many factors, such as the lack of infrastructure and planning in the country's energy sector, as seen in the lack of investment in power production and distribution, which resulted in billions of reais in losses to public coffers. Brazilians were forced to ration power, mainly by paying more for household electricity in proportion to their consumption level.

In this sensitive environment, in which rapid and effective measures were needed to resolve the energy problem quickly, directives for programs to confront the electricity crisis were created with great haste. In this context wind farms and other alternative energy sources were categorized as small-scale environmental impact, with the requirement that investors had to present a RAS, a simplified report that considered environmental aspects relating to site, installation, and operation as assistance in conceding the required prior or initial environmental license. By law, this document should contain information relative to an environmental diagnosis of the region in which the project would be built, the description and identification of environmental impacts, and means for control, mitigation, and compensation.

However, in Ceará, the lack of precision in basic information of the wind-farm projects demonstrates the precarious nature of physical and social data collected during the production of the documents. These materials are normally produced by local consultancies that usually recycle information from previous work using low standards of quality and reliability. This weakness increases the possibility of negative impacts caused by wind farm construction, seen in a case study of Trairi, on the western coast, by Oliveira (2014), and, many times, traditional communities are not even represented in the proposal's contents, or they occupy an irrelevant portion of it.

One fact that shows the low quality of the consultancies hired by wind-energy firms in Ceará is that the owner of the largest firm in this area, which produced 50\% of the RAS for Ceará's operational wind farms (ARAÚJO, 2015), was sentenced in 2014 to 32 years in prison, just like nearly all other state environmental managers in that year who were caught in a federal police operation, begun in 2008, for having produced biased environmental impact studies and issued fraudulent licenses, among other illegal acts (O POVO on line, 2014).

To this issue is added lack of coherent policies for guaranteeing access rights to land among traditional populations in Ceará and poor compliance with legal guidelines on coastal land use. For example, there is no demarcation of federal land in coastal Ceará even through the legal guidelines have existed since the first half of the nineteeenth century and legal regulations began in the twentieth century. In Ceará, these lands began to be formally demarcated only in 2010, when technical norms of the Superintendency of Federal Property (Superintendência do Patrimônio da União, SPU) in Ceará were established. Because the state government lacks financial resources and technical staff, according to its institutional discourse, and, in our view, lack of political will to demarcate federal land in the entire coastline, this work has been outsourced to the developers who, after demarcating federal lands, submit their claims to the state, which authorizes construction in areas outside public land.

Simas; Pacca (2013), in a Brazilian case study and a document on Ceará produced by the Ceará state government (CEARÁ, 2001) have declared that wind farms may coexist with diverse economic activities such as livestock and agriculture and that landowners are not pushed off their lands, and they continue residing on their lands and may increase rural productivity, based on the investment of resources obtained through royalties and rents. However, this only happens where secure land possession and legal stability of property exist, which is absent in traditional communities of coastal Ceará, who live as "good-faith occupants" on their territory and do not have legal guarantees to remain (LIMA, 2009). 
This situation is not limited to Brazil, as evidenced by the case of the Tehuantepec isthmus, where 97\% of Mexico's wind farms are located in what Juaréz-Hernandéz; León (2014) consider to be a means of obtaining wind power that favors the firms, which concentrate economic benefits and limit benefits to local communities. Information regarding land rental is non-existent and there is no prior consultation or other form of knowledge dissemination to local people, similarly to Ceará.

Juaréz-Hernandéz; León (2014) note the cooptation of community representatives as a strategy of the firms to obtain greater economic benefits, which is seen by Sauer; Silva Junior (2012) as "repressive strategies" listed as: (i) political isolation, removing a voice and legitimacy to local demands; (ii) co-optation, the concession of small privileges to local groups or important leaders, normally done by offering money, seeking to weaken social movements, as Araújo (2015) showed in Amontada, on the western coast, and (iii) repression with the use of police force, exemplified in the case of Cumbe, a quilombola community on the eastern coast (SANTOS, 2014).

In this situation it is valid to consider the view of Saidur et al. (2011), who note that the increase in energy consumption and the necessity of countries to develop a "clean" and diversified energy portfolio portrays wind firms as salvation of the nation and, for this reason, governments often accept the activities of this industry without imposing many restrictions. This leads to various impacts.

Sauer; Silva Junior (2012) argue that, according to the World Bank, in 2010 global land demand was enormous, especially starting in 2008, and the international interest for land in Latin America (Brazil, Argentina, and Uruguay) and Sub-Saharan Africa caused an increase in prices, which exacerbated land disputes and created pressure to ignore territorial rights. This situation is exemplified in a report in the Diário do Nordeste, dated 9 September 2009 (DIÁRIO DO NORDESTE, 2009), which discusses the inauguration of a wind farm in Xavier, on the west coast of Ceará, and notes difficulty in demarcating large areas and finding available land as obstacles to the growth of wind power.

Because of this and other issues relating to the impact of wind-farm construction, the negative perception of wind power has increased in many countries (PASQUALLETI, 2011), on all continents, with resistance among Mexican people against wind farms (JUARÉZ-HERNANDÉZ; LEÓN, 2014), the burning of turbines in Scotland and the death of a protester in China (ANG, 2005; DAVIES, 2007, BOHN; LANT 2009, PENICUIK, 2010). High social acceptance of wind power is observed where payment of royalties and rents to landowners where turbines are sited and where positive economic impacts are visible (BRANNSTROM et al., 2011; SLATTERY et al., 2012).

In Brazil some social movements against wind-farm construction, especially in Ceará, are already visible through the use of petitions by humanitarian and environmental organizations and associations of traditional fishers, family farmers, and indigenous groups in coastal Ceará. The first (2012) and second versions (2014) of a meeting promoted by the Instituto Terramar were titled "Wind power: environmental conflicts and injustices in the coastal zone". In 2015, public hearings in Ceará discussed the impacts of wind farms on communities, using the title "Contradictions of wind energy in Ceará". The political objective of the hearings was to discuss the negative territorial impacts of wind farm construction with communities and possible alternative locations.

In this context it is important to indicate that while Brazilian states and federal government made legislation that conceded benefits to wind-power investors more flexible, some municipalities, which suffer the direct negative impacts of wind farms, have tried to reduce problems by creating fragile legal statutes, as in the case of São Miguel do Gostoso, in Rio Grande do Norte, which in 2013 approved a law that limited wind-farm construction to $2 \mathrm{~km}$ from the high tide line (TRIBUNA DO NORTE, 2014). 
Acselrad (2004), Sant'Ana Junior and Silva (2010) and Leroy and Meireles (2013) describe the state logic, in alliance with wind-power firms, that encroaches on traditional communities and usurps land-possession and citizen rights, as a process of making social groups invisible through the perception of territory as unoccupied space available for economic interventions involving large projects, such as the generation of wind power through the negation of geographical location of the communities. These communities are normally not represented on the maps that comprise the most important document for environmental licensing for wind farms, the RAS.

Collusion between the state government and representatives of large corporations is exemplified in the text of the minutes of meetings of the Sectoral Board of Ceará Wind Power (Câmara Setorial de Energia Eólica do Ceará) on 17 January 2014, in which a representative of a multinational wind-energy firm offered to write the text that would serve as basis for state legislation that covered fiscal incentives for wind-farm construction, aiming to make Ceará's regulations similar to those of São Paulo state, considered by firm representatives as ideal to conduct business.

\section{PROPOSALS FOR BETTER MANAGEMENT OF WIND-FARM IMPLEMENTATION POLICIES IN CEARÁ}

It is important to consider experiences of other countries in relation to best practices for planning, constructing, and operating wind farms. These include local and regional plans for wind power in Germany, Ireland, and Australia, which identify clear guidelines for integrating wind turbines with other land uses (GL, 2010; IWEA, 2012; IWEA, 2011; CEC, 2013). As Jabber (2013) indicates, municipal planning may provide goals and means relating to implementing wind-farm projects, even including detailed information on siting turbines, the number of projects, and the relevance of visual impacts on landscapes. To accomplish this, local residents must be consulted with regard to information about the projects and negotiations relating to the siting of the project and the overall size of the projects.

Planners and local residents should decide if the project is compatible with existing land uses and whether it will negatively modify the overall characteristics of the site and harm established communities (VARUN; INTER, 2009; EWEA, 2009), because local residents bear the greatest impacts (BROWN, 2011; MUNDAY et al., 2011).

In this regard, Dincer (2000) and CEC (2013) indicate that information and education are the main factors in the success of sustainable energy development, public awareness, and community involvement. Wind velocity never should be the only criterion for siting a wind farm because other factors, such as an open and transparent negotiation of the distribution of benefits generated, including local values among criteria in the final decision making, should also be considered (ZOGRAFOS; SALADIÉ, 2012).

Brannstrom et al. $(2011 ; 2015)$ report the importance of positive social impacts caused by wind farms in local communities as a result of royalty and land-rent payments to landowners that were negotiated with renewable energy firms, which is important for national-scale power generation. In situations with no adequate planning, wind farms may be perceived as a "technological hazard" that may create serious problems such as psycho-social distress in entire communities (WALKER et al., 2015).

Brown (2011) proposes that Ceará's wind farms should develop programs for professional training, land-rent payments, and long-term investments in local education, health, and infrastructure, in addition to guarantees to stable access routes. Munday et al. (2011) argued for other benefits, such as the possibility for the host community to receive cheaper power and the construction of observation towers for tourism. 
Molina; Tudela (2008) argue for the importance of zoning plans in territorial land-use planning exercises to propose sites that attend to environmental and social demands and that are more suited to wind-farm construction. Zoning should be carried out in partnership with all social actors and consider the physical, territorial, historical, cultural, and conservationist aspects of host communities. Tangible aspects of this argument may be seen in one município in northeastern Brazil, when a representative of Rio Grande do Norte's environmental licensing agency declared in a media release that ecological zoning of the state's eastern coast did not consider wind power and, because of this, it was necessary to create a new document that considered how to best locate wind-power projects (TRIBUNA DO NORTE, 2014).

\section{FINAL CONSIDERATIONS}

Wind energy is not free from impacts, but many may be minimized to avoid "imposition" on communities (PASQUALETTI 2011). If we want to advance wind power to new frontiers, as Lima et al. (2015) indicate in studies that estimate the production of offshore wind energy in coastal Ceará, we should develop better forms of planning relating to siting wind farms and the management of benefits generated by wind power.

Although Brown's (2011) suggestions are naive regarding how Ceará's wind industry growth should include sharing economic gains with best practices in communities, it is clear that the development of policies that do not include direct participation of society will generate conflict among different institutional levels and cause severe social and environmental problems, the dimensions of which may not be known for decades.

Reflecting on our work, we should emphasize that the situation of land-tenure insecurity in relation to the territorial permanence of traditional people and corruption in the executive branch of government that should assure the rights of citizens and environmental preservation creates an extremely unfavorable environment for the existence of traditional communities and cultural diversity of coastal Ceará. It is important to recognize that changes are inevitable, but we should identify processes that arrive without planning and those that are done with participatory methods and intensive participation by communities. In agreement with Lima (2009), we argue that even though wind power is considered clean and renewable, the installation of wind farms in Ceará is causing large impacts on the environment and traditional livelihoods of local residents, but we can suggest some solutions.

Based on this case study, a critical reading of the scientific, technical, and scholarly literature, and international best-practices guidelines for wind power, we offer several suggestions for improving wind-farm siting in Ceará: (i) legal security for land possession by traditional communities; (ii) payment of royalties and rents to community associations; (iii) reduction in electricity cost to local residents; (iv) creation of permanent programs for education and best practices directed to local communities; (v) construction of legal standards that regulate wind-power implementation at state and municipal scales through municipal statutes and plans; (vi) production of environmental impact studies that are based on the premise of public awareness, broad information, and communication strategies regarding the benefits and possible harms to environment, society, and human health; and (vii) state zoning studies that identify compatibility of regions in the state with wind-farm implementation and broad social participation.

Finally, we should note the lack of research on many aspects relating to renewable power in Brazil. Geographical research should describe and quantify social acceptance or rejection of wind 
farms to facilitate comparisons with other Brazilian cases and with the international literature, aiming to: (i) understand to land-tenure dimension and establish dialogue with research on territorial impacts of renewable power; (ii) analyze the linkages between investors and the many intermediaries, such as local elites, to de-mystify financial and social relations; (iii) understand political strategies of oppositional groups to facilitate comparisons with national and global cases relating to opposition to renewable power and infrastructure projects; (iv) research means to improve the negotiating capacity between communities and wind-power investors. Geographers with the ability to dialog with a renewable energy source as a partial solution to future energy challenges have much to contribute to reduce environmental and social contradictions of wind power in Brazil.

\section{ACKNOWLEDGEMENTS}

The authors thank the Ministério da Educação and the Coordenação de Aperfeiçoamento de Pessoal do Ensino Superior for research funding (CAPES-PVE Proc. N. 88881.068108/2014-01, "Impactos da Energia Eólica no Litoral do Nordeste: perspectivas para a construção de uma visão integrada da produção de energia limpa") and the Ministério da Ciência, Tecnologia e Inovação and the Conselho Nacional de Desenvolvimento Científico e Tecnológico for the post-doctoral scholarship to the first author (CNPq/ Ciência Sem Fronteiras Proc. N. 233291/2014-8 "Impactos Socioambientais da Energia Eólica: um estudo comparativo em áreas do Brasil, litoral do Ceará, e Estados Unidos, sul do Texas").

\section{BIBLIOGRAPHY REFERENCE}

ACSELRAD, H. Conflitos Ambientais - a atualidade do objeto. In: Acselrad, H. (org.). Conflitos ambientais no Brasil. Rio de Janeiro: Relume Dumará/ Fundação Heinrich, 2004. p. 7 - 12.

ABEEOLICA (Associação Brasileira de Energia Eólica). Boletim anual de geração eólica: 2014. São Caetano do Sul: Pigma Gráfica e Editora Ltda., 2015. 16p.

ABEEÓLICA (Associação Brasileira de Energia Eólica). Eólicas batem recorde de geração no Nordeste. São Paulo: Associação Brasileira de Energia Eólica, 2015. 1p.

ALBIERO, D.; DAHER, S.; MONTEIRO, L. A.; CANAFÍSTULA, F. J. Turbina eólica para agricultura familiar do semiárido com inovações tecnológicas para baixas velocidades de vento. Revista Ciência Agronômica, v. 45, n. 1, p. 186-196, 2014.

ANEEL. Atlas de energia eólica do Brasil. Brasília: ANEEL, 2005. 243p.

ANG, A. Chinese village surrounded after shootings. 2005. Disponível em: <http://www.activeboard. com/forum.spark?aBID=33011\&p=3\&topicID=5024635>. Acesso em: 25 fev. 2016

ARAÚJO, M. S. M.; FREITAS, M. A. V. Acceptance of renewable energy innovation in Brazil—case study of wind energy. Renewable and Sustainable Energy Reviews, v. 12, p. 584-591, 2008.

ARAÚJO, J. C. H. As Tramas da Implementação da Energia Eólica na Zona Costeira do Ceará: legitimação e contestação da "energia limpa". 2015. 185p. Dissertação (Programa de Pós-Graduação em Planejamento Urbano e Regional) - Universidade Federal do Rio de janeiro, Rio de Janeiro, 2015.- não é a versão final, ou a data é de 2016.

BARCELLA, M. S; BRAMBILLA, F. R. Energia eólica e os impactos socioambientais: estudo de caso em parque eólico do Rio Grande do Sul, Brasil. Revista de Ciências Ambientais, vol.6, n.2, p. 5-18, 2012.

BOHN, C.; C. LANT. Welcoming the wind? Determinants of wind power development among U.S. States. The Professional Geographer, v. 61, n. 1, p. 87-100, 2009. 
BRANNSTROM, C.; JEPSON, W.; PERSONS, N. Social Perspectives on Wind-Power Development in West Texas. Annals of the Association of American Geographers, v. 101, p. 839-851, 2011.

BRANNSTROM, C.; TILTON, M.; KLEIN, A.; JEPSON, W. Spatial distribution of estimated wind-power royalties in west Texas. Land, v. 4, p. 1182-1199, 2015.

BRASIL. Resolução n. 237, de 19 de dezembro de 1997. 1997. Disponível em: <http://www.mma. gov.br/ port/conama/res/res97/res23797.html>. Acesso em: 25 fev. 2016

BRASIL. Atlas do potencial eólico brasileiro. Brasília: Ministério de Minas e Energia, 2001a, 42p.

BRASIL. Resolução n. 279 de 27 de julho de 2001. 2001b. Disponível em: <http://www.mma.gov.br/port/ conama/res/res01/res27901.html.>. Acesso em: 25 fev. 2016

BRASIL. Ministério das Minas e Energia. Resenha Energética Brasileira: exercício de 2014. Brasília, junho/2015, 32p.

BROWN, K. B. Wind power in northeastern Brazil: Local burdens, regional benefits and growing opposition. Climate and Development, v. 3, p. 344 - 360, 2011. doi: 10.1080/17565 529.2011.628120

BRASIL, 2014. Resolução n. 462, de 24 de julho de 2014. Disponível em: <http://www.mma. gov.br/port /conama/legiabre.cfm?codlegi=703>. Acesso em: 25 fev. 2016

CEARÁ. Estado do Ceará: Atlas do potencial eólico. Fortaleza: Secretaria de Infra-estrutura, 2001, 32p.

CEARÁ. Projeto das usinas eólicas do estado do Ceará: relatório técnico. Fortaleza: Secretaria de Infra-Estrutura, 2004, 19p.

CEARÁ. Atração de investimentos no estado do Ceará: mapa territorial de parques eólicos. Fortaleza: CEDE/ ADECE, 2010, 74p.

CEC. Community Engagement Guidelines for the Australian Wind Industry. Southbank, 2013, 80p.

CPFL Energia. Relatório anual 2011. Campinas, 2011, 288p.

DAVIES, N. 2007. Organized chaos in Oaxaca: PFP evicts farmers to construct wind park on the Isthmus of Tehuantepec. Disponível em: <http://www.narconews. com /Issue45/article2611.html >. Acesso em: 25 fev. 2016

DIÁRIO DO NORDESTE, 2009c. Ceará conta com 10 usinas eólicas em operação. (9/9/2009). Disponível em: <http://www.mxtrading.com.br/blog/?tag=usina-eolica $>$. Acesso em: 25 fev. 2016

DINCER, I. Renewable energy and sustainable development: a crucial review. Renewable and Sustainable Energy Reviews, v. 4, p. 157 - 175, 2000.

EWEA. Wind Energy - The Facts (WindFacts). 2009. Disponível em: $<$ http://www.wind-energy-the-facts. org/>. Acesso em: 25 fev. 2016

FERREIRA, A. G.; MELLO, N. G. S. Principais sistemas atmosféricos atuantes sobre a Região nordeste do Brasil e a influência dos oceanos Pacífico e Atlântico no clima da região. Revista Brasileira de Climatologia, v. 1, n. 1, p. $15-28,2005$.

FILGUEIRAS, A.; SILVA, T. M. V. Wind energy in Brazil-present and future. Renewable and Sustainable Energy Reviews, v. 7, p. 439-451, 2003.

FGVEASP. SIIF Énergies investe R\$ 500 milhões na Central Eólica Praia Formosa. (09/09/2009). Disponível em: $<$ http://gvces.com.br/siif-energies-investe-r-500-milhoes-na-central-eolica-praia-formosa?locale=pt-br\#sthash.bDUkA6jj.dpuf>. Acesso em: 25 fev. 2016

GESEL. SIIF Énergies inaugura Praia Formosa. (4/9/2009). Disponível em: http://www.nuca.ie.ufrj. br/ blogs/gesel-ufrj/index.php?/archives/4607-Siif-nergies-inaugura-Praia-Formosa.html. Acesso em: 25 fev. 2016

GL. Rules and guidelines industrial services: guideline for the certification of Wind Turbines. Hamburg, 2010, 339p.

GWEC. Global wind report: annual market update 2012. Belgium, 2013, 80p.

GWEC. Global wind report: annual market update 2013. Belgium, 2014, 80p.

GWEC. Global wind report: annual market update 2014. Belgium, 2015, 80p. 
IWEA. Best Practice Guidelines for the Irish Wind Energy Industry. Osberstown: Fehily Timoney \& Company, 2012, 123p.

IWEA. Health and safety guidelines for the onshore wind industry on the Island of Ireland. Osberstown: Fehily Timoney \& Company, 2011, 59p.

JABBER, S. Environmental Impacts of Wind Energy. Journal of Clean Energy Technologies, v. 1, n. 3, p. 251 - 254, 2013. doi: 10.7763/JOCET.2013.V1.57

JACOBSON, M. Z.; DELUCCHI, M. A. Providing all global energy with wind, water, and solar power, Part I: Technologies, energy resources, quantities and areas of infrastructure, and materials. Energy Policy, v. 39, p. 1154-1169, 2011.

JUARÉZ-HERNANDÉZ, S.; LEÓN, G. Energía eólica en el istmo de Tehuantepec: desarrollo, actores y oposición social. Revista Problemas del Desarrollo, v. 178, n. 45, p. 139 - 162, 2014.

LEROY, J. P.; MEIRELES, A. J. A. Povos indígenas e comunidades tradicionais: os visados territórios dos invisíveis. In: Porto, M. F.; Pacheco, T.; Leroy, J. P. Injustiça ambiental e saúde no Brasil: o mapa de conflitos. Rio de Janeiro: FIOCRUZ, 2013, p. 115 - 122.

LIMA, M. C. Pesca artesanal, carcinicultura e geração de energia eólica na zona costeira do Ceará. Revista Terra Livre - AGB, v. 31, p. 1 -16, 2009.

LIMA, D. K.S.; LEÃO, R. P.S.; SANTOS, A. C.S.; MELO, F. D.C.; COUTO, V. M.; NORONHA, A. W. T.; OLIVEIRA JUNIOR, D. S. Estimating the offshore wind resources of the State of Ceará in Brazil. Renewable Energy, 83, 203 - 221, 2015.

MEIRELES, A. J; GORAYEB, A.; LIMA, G. S.; SILVA, D. R. F. Impactos socioambientais da energia eólica no litoral cearense. In: Correia, L. J. A.; Oliveira, V. P. V.; Maia, J. A. Evolução das paisagens e ordenamento territorial de ambientes interioranos e litorâneos. Fortaleza: Expressão Gráfica, 2015, pp. 156 - 169. MEIRELES, A. J. A., GORAYEB, A., SILVA. D. R. F.; LIMA, G. S. Socio-environmental impacts of wind farms on the traditional communities of the western coast of Ceará, in the Brazilian Northeast. In: Conley, D.C.; Masselink, G., Russel, P. E., and O'Hare, T. J. (eds.), Proceedings of the 12th International Coastal Symposium. Journal of Coastal Research, Special Issue No 65, 2013, pp. 81-86.

MENDES, J. S.; GORAYEB, A.; BRANNSTROM, C. Diagnóstico participativo e cartografia social aplicados aos estudos de impactos das usinas eólicas no litoral do Ceará: o caso da Praia de Xavier, Camocim. Geosaberes, v. 6, n. 3, pp. $243-254,2016$.

MOLINA, R. J.; TUDELA, S. M. L. Elección de criterios y valoración de impactos ambientales para la implantación de energía eólica. Papeles de Geografía, v. 47-48, p. 171-183, 2008.

MONTENEGRO, C., 2013. O licenciamento ambiental simplificado para empreendimentos de geração de energia eólica e a realidade dos órgãos ambientais estaduais. Disponível em: $<$ http://carinacgm.jusbrasil. com.br/artigos/112021848/o-licenciamento-ambiental-simplificado-para-empreendimentos-de-geracao-de-energia-eolica-e-a-realidade-dos-orgaos-ambientais-estaduais $>$. Acesso em: 25 fev. 2016

MUNDAY, M.; BRISTOW, G.; COWELL, R. Wind farms in rural areas: how far do community benefits from wind farms represent a local economic development opportunity? Journal of Rural Studies, 27, 1 - 12, 2012. O POVO on line. Operação Marambaia: 11 condenados por crime ambiental. (3/12/2014). Disponível em: $<$ http://www.opovo.com.br/app/opovo/cotidiano /2014/12/03/noticiasjornalcotidiano,3357067/operacao-marambaia-11-condenados-por-crime-ambiental.shtml>. Acesso em: 25 fev. 2016

OLIVEIRA, R. F. Impactos da Energia Eólica: Impactos Ambientais Negativos na Dinâmica Costeira do Município de Trairi, Ceará, Brasil. 2014. 178p. Dissertação (Programa de Pós-Graduação em Geografia) Universidade Federal do Ceará, Fortaleza, 2014.

PACHECO, T. Racismo Ambiental: expropriação do território e negação da cidadania. In: Superintendência de Recursos Hídricos (org.), Justiça pelas águas: enfrentamento ao Racismo Ambiental. Salvador: Superintendência de Recursos Hídricos, 2008, p. 11-23.

PASQUALLETI, M. J. Social barriers to renewable energy landscapes. Geographical Review, v. 101, n. 2, p. 201-223, 2011. 
PENICUIK ENVIRONMENT PROTECTION ASSOCIATION. 2010. Auchencorth wind farm appeal rejected. Disponível em: $<\mathrm{http}: / /$ www.auchencorth.org.uk/>. Acesso em: 25 fev. 2016

PIRES, A. Os royalties nas eólicas. (01/12/2011). Disponível em: $<$ http://www.anacebrasil.org.br/ portal/ index.php/leilao/item/888-os-royalties-nas-e\%C3\%B3licas>. Acesso em: 25 fev. 2016

SAIDUR, R.; RAHIM, N. A. ; ISLAM, M. R. ; SOLANGI, K. H. Environmental impact of wind energy. Renewable and Sustainable Energy Reviews, v. 15, p. 2423-2430, 2011.

SANT'ANA JUNIOR, H. A.; SILVA, S. C., 2010. Taim: conflitos socioambientais e estratégias de defesa do território. Revista Pós Ciências Sociais, v. 7, n. 13, p. 159 - 172, 2010.

SANTOS, A. N. G. A energia eólica no litoral do NE no Brasil: desconstruindo a "sustentabilidade" para promover "justiça ambiental". Heinrich-Böll-Stiftung e-paper, nov/2014, 1 - 18.

SAUER, S.; SILVA JUNIOR, G. L. Territorialidade e luta por direitos. In: Movimento Nacional de Direitos Humanos et al. (eds.). Direitos humanos no Brasil 3: diagnósticos e perspectivas. Passo Fundo: IFIBE, 2012, p. $127-135$.

SCHEIDEL, A.; SORMAN, A. H. Energy transitions and the global land rush: Ultimate drivers and persistent consequences. Global Environmental Change, vol. 22, p. 588-595, 2012.

SCHULTZ, D. J.; AMARANTE, O. A. C; ROCHA, N. A. R.; BITTENCOURT, R. M.; SUGAI, M. R. B. Sistemas complementares de energia eólica e hidráulica no Brasil. Espaço Energia, v. 3, p. 1-7, 2005.

SILVA, R. C.; MARCHI NETO, I.; SEIFERT, S. S. Electricity supply security and the future role of renewable energy sources in Brazil. Renewable and Sustainable Energy Reviews, v. 59, p. 28-341, 2016.

SILVA, S. S. F.; CÂNDIDO, G. A. Matriz energética limpa e renovável: um desafio para o Planejamento Energético Nacional e uma oportunidade para a Região Nordeste do Brasil. Espacios, v. 36, n. 15, 13p, 2015.

SILVA, K. F. Controle e Integração de Centrais Eólicas à Rede Elétrica com Geradores de Indução Duplamente Alimentados. 2006. 270p. Tese (Escola Politécnica) - Universidade de São Paulo, São Paulo, 2006.

SIMAS, M.; PACCA, S. Energia eólica, geração de empregos e desenvolvimento sustentável. Estudos Avançados, v. 27, n. 77, p. 99 - 115, 2013.

SLATTERY, M. C.; JOHNSON, B. L.; SWOFFORD, J. A.; PASQUALETTI; M. J. The predominance of economic development in the support for large-scale wind farms in the U.S. Great Plains. Renewable and Sustainable Energy Reviews, v. 16, p. 3690-3701, 2012.

SOUZA, A. D. Avaliação da Energia Eólica para o Desenvolvimento Sustentável Diante das Mudanças Climáticas no Nordeste do Brasil. 2010. 168p. Dissertação (Programa de Pós-Graduação em Engenharia Civil) - Universidade Federal de Pernambuco. Recife, 2010.

TRIBUNA DO NORTE. Lei restringe instalação de eólicas. (13/05/2014). Disponível em: <http://www. tribunadonorte.com.br/noticia/lei-restringe-instalacao-de-eolicas/281672>. Acesso em: 25 fev. 2016

VARUN, P.R.; INDER, K.B. Energy, economics and environmental impacts of renewable energy systems. Renewable and Sustainable Energy Reviews, v. 13, p. 2716-2721, 2009.

VRIES, B. J. M.; VUUREN, D. P.; HOOGWIJK, M. M. Renewable energy sources: their global potential for the first-half of the 21st century at a global level: an integrated approach. Energy Policy, v. 35, p. 2590-2610, 2007.

WALKER, C.; BAXTER, J.; OUELLETTE, D. Adding insult to injury: the development of psychosocial stress in Ontario wind turbine communities. Social Science \& Medicine, v. 133, p. 358 - 365, 2015.

ZOFRAGOS, C.; SALADIÉ, S. La ecología política de conflictos sobre energía eólica: un estudio de caso en Cataluña. Documents d'Anàlisi Geogràfica, v. 58, n. 1, p. 177-192, 2012. 
